$1-1-1977$

\title{
Impact of alternative marketing patterns for West Virginia Fresh market apples
}

Howard R. Scott

Robert L. Jack

Follow this and additional works at: https://researchrepository.wvu.edu/ wv_agricultural_and_forestry_experiment_station_bulletins

\section{Digital Commons Citation}

Scott, Howard R. and Jack, Robert L., "Impact of alternative marketing patterns for West Virginia Fresh market apples" (1977). West Virginia Agricultural and Forestry Experiment Station Bulletins. 656.

https://researchrepository.wvu.edu/wv_agricultural_and_forestry_experiment_station_bulletins/557 @ WVU. It has been accepted for inclusion in West Virginia Agricultural and Forestry Experiment Station Bulletins by an authorized administrator of The Research Repository @ WVU. For more information, please contact ian.harmon@mail.wvu.edu. 


\section{Impact of Alternative} Marketing Patterns for

\section{West Virginia Fresh Market Apples}

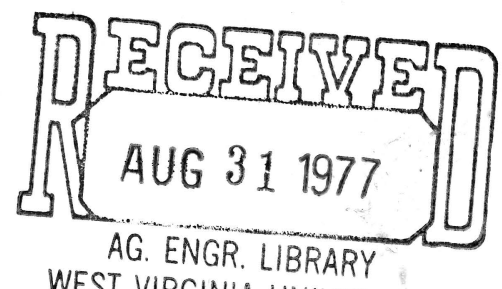

WESTIVIRGHOHA UNIVERSITY

March 1977

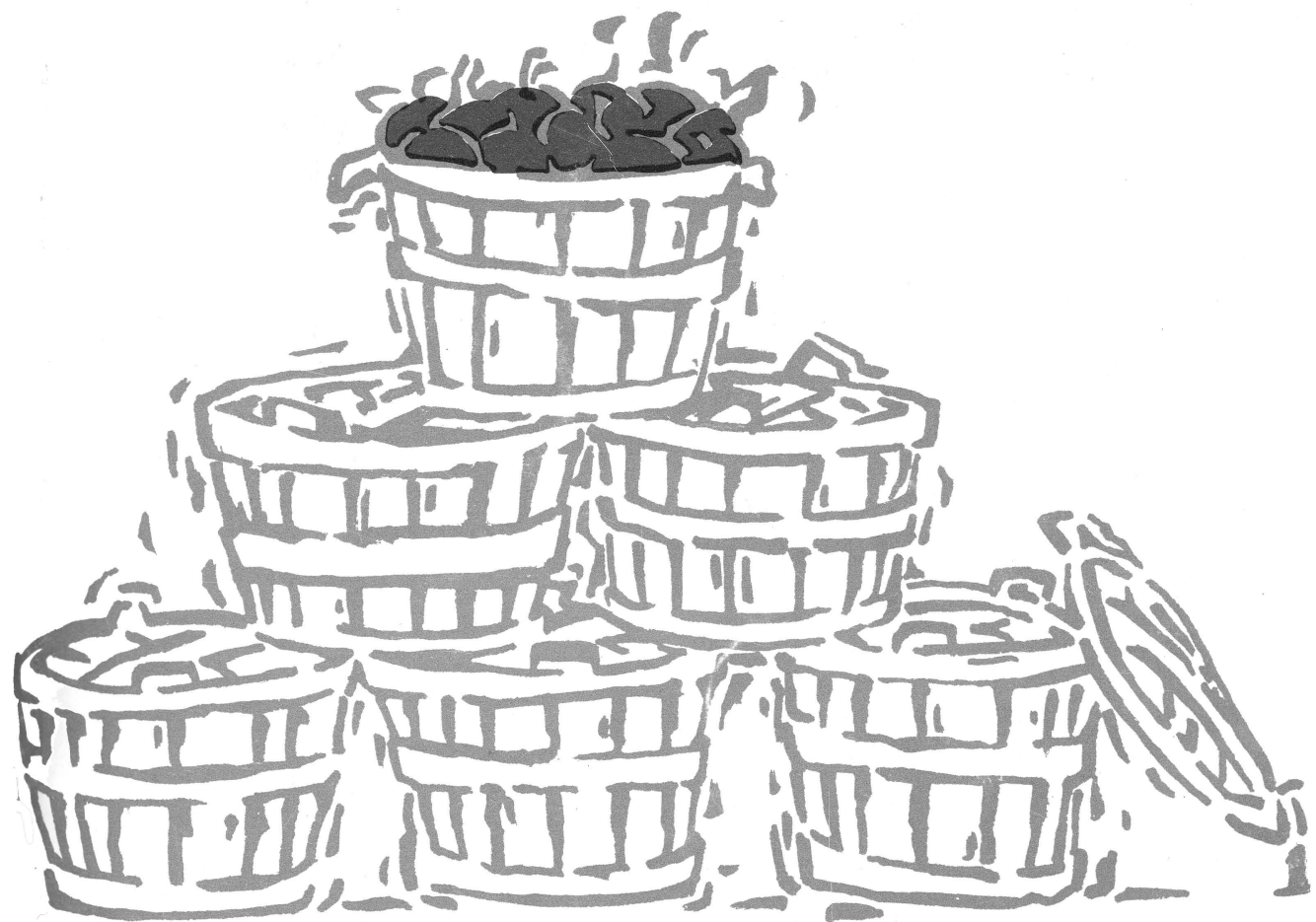

West Virginia University

Agricultural and Forestry Experiment Station
$\$ 127$
. El
ho. 656 
Blank Page in Original Bulletin 


\section{SUMMARY}

Apple production accounts for approximately $\$ 18$ million or 48 percent of West Virginia's annual crop sales. Approximately half of the apples produced are sold in the fresh market and half in the processing market. Seasonal unload data indicate that West Virginia producers sell a large percentage of their fresh apples in the fall market when prices are at a seasonal low.

The purpose of this study was to determine the effect of alternative marketing patterns on adjusted net returns from West Virginia apples sold in the Baltimore fresh market. Five-year average monthly data (1969-73) for unloads, retail prices, growers' share of retail value plus quarterly price flexibility coefficients for the 1968-69 season, and storage cost estimates were used in a linear program model to analyze different marketing patterns.

In the normal marketing pattern (Solution I), five-year average monthly data for all states reporting unloads of apples in the Baltimore market were used to determine the net income to West Virginia producers $-\$ 555,401$. This return served as the basis for comparing net returns obtained in other solutions.

When West Virginia's marketing pattern was reversed (Solution II), net returns increased to $\$ 606,561$. The return in Solution II was $\$ 51,160$, or $\$ 8$ per thousand pounds greater than Solution I.

When West Virginia's average annual unloads were divided by nine to obtain an even monthly volume for the market season (Solution III), net return was $\$ 585,783$. The return in Solution III was $\$ 20,778$, or $\$ 4$ per thousand pounds less than Solution II. Since the adoption of Solution III required a smaller increase in CA storage capacity and a more gradual change than the reversed marketing pattern in Solution II, Solution III was used for analyzing three additional alternatives.

In Alternative I the five-year average monthly unloads from Washington were decreased ten percent. Total net return to West Virginia growers was $\$ 587,487$, or $\$ 1,704$ greater than Solution III.

In Alternative II, unloads from Washington were increased ten percent for each month. Total net return for West Virginia was $\$ 584,080$. This return was $\$ 3,407$ less than Alternative I.

In Alternative III, unloads from West Virginia were increased ten percent each month. Total net return for the season was $\$ 642,421$. This return was the largest of all solutions and alternatives tested but the net return per thousand pounds was the same as for Solution III, Alternative I, and Alternative II. 


\section{ACKNOWLEDGMENT}

This bulletin is published as a contribution to the Northeast Regional Marketing Research Project (NE-88). The West Virginia research for this publication was supported by both state and regional research funds.

\section{THE AUTHORS}

Howard R. Scott was a Graduate Research Assistant in Agricultural Economics; Robert L. Jack is Agricultural Economist.

West Virginia University Agricultural and Forestry Experiment Station

College of Agriculture and Forestry

Dale W. Zinn, Director

Morgantown 


\section{Impact of Alternative}

\section{Marketing Patterns for}

\section{West Virginia Fresh Market Apples}

\section{Howard R. Scott and Robert L. Jack}

West Virginia's annual apple production of approximately 200 million pounds ranks seventh in commercial apple production in the United States, and fifth among the eastern states. Nearly one-half, or 100 million pounds, of the production goes into fresh sales each year. In 1973, cash farm receipts in West Virginia totaled $\$ 152.6$ million. All crops accounted for $\$ 37.1$ million, and apples accounted for $\$ 17.9$ million or 48 percent of the state's annual crop sales. ${ }^{1}$

Unload data ${ }^{2}$ indicate the principal outlets for West Virginia apples which are sold for fresh consumption are the Baltimore, Philadelphia, Pittsburgh, and Washington, D.C., markets. West Virginia growers market a large proportion of their apples soon after harvest when prices are low. However, growers from other states continue to supply markets during the last half of the season when the prices are high. Current marketing patterns used by West Virginia growers possibly could be improved by extending the marketing period through greater usage of controlled atmosphere (CA) storage.

\section{PURPOSE}

The purpose of this study was to analyze how a change in sales distribution affected net income received by West Virginia growers who sold apples in the Baltimore fresh market over the entire market season.

\section{METHODOLOGY}

This study analyzed marketing of apples produced in the Appalachian District, with the greatest emphasis on West Virginia. The Baltimore fresh apple

${ }^{1}$ United States Department of Agriculture. Farm Income State Estimates 1949-1973. Economic Research Service, FIS 224 Supplement, September 1974.

2 "Unload data" means the number of carlots that were reported by month and origin. Through December 1970, a carlot consisted of 820 cartons weighing an average of 42.5 pounds. Beginning January 1971 a carlot consists of 900 cartons with an average weight of 42.5 pounds. 
market served as the basis for analysis since West Virginia growers sell nearly fifty percent of their reported unloads through this market. ${ }^{3}$

Secondary data comprised the larger portion of the data used in the study. Linear programming was used (MPS-360 Control Program) with the objective of maximizing net returns from the sales of West Virginia apples in the Baltimore fresh market during the 1969-73 crop years. Five-year average retail price by months, volume of apples sold by month and origin, grower's share of retail value, and cumulative cost for storage of apples were used in the program. With this information, the problem was to determine if net return to West Virginia growers could be increased by distributing sales more evenly throughout the market season.

\section{Definitions of Concepts}

The following discussion is included to give the reader an understanding of the concepts and how data were used to calculate figures presented in this study.

Quantity Marketed. The volume of fresh apples used in the analysis was the average quantity marketed by month and origin for the years 1969-73. Apple unloads in Baltimore from Washington, West Virginia, and other states were tabulated for each month of the five years and averaged to derive an average or representative year to use in the analysis.

Retail Prices. Monthly retail prices per pound for fresh apples sold in the Baltimore market from the 1968-69 crop through the 1973-74 crop were used to compute a five-year average annual and average monthly price. ${ }^{4}$ By using the average retail price, any bias introduced by a large or small crop of apples was minimized. Since the price included all apples sold, regardless of grade, the retail prices used may be biased downward (Appendix A).

Price Flexibilities. A price flexibility coefficient indicates the percentage change in price associated with a one percent change in quantity supplied. Edman's price flexibility coefficients ${ }^{5}$ for apples were used to estimate the impact a change in monthly or annual quantity would have on retail price in the Baltimore market. These coefficients were used in the analysis of the various alternatives examined in this study (Appendix B).

${ }^{3}$ United States Department of Agriculture, Fresh Fruit and Vegetable Unloads in Eastern Cities, 1967-73 (Washington, D.C.: Consumer and Marketing Service, Fruit and Vegetable Division, Market News Branch).

${ }^{4}$ Alfred J. Burns and Joseph C. Podany, Prices and Spreads for Selected Fruits Sold Fresh in Major Markets, 1967/68-1973/74, Economic Research Service, Agricultural Economic Report No. 295 (Washington, D.C.: United States Department of Agriculture, August 1973) pp. 3-25.

${ }^{5}$ Victor G. Edman, Retail Demand for Fresh Apples, Economic Research, Marketing Research Report 952 (Washington, D.C.: United States Department of Agriculture, April 1972) pp. 12-13. 
Total Retail Value. Total annual and monthly retail values were determined by multiplying quantity of apples marketed by average retail price.

Growers' Gross Return. ${ }^{6}$ Data for growers' share of retail value were taken from a study published by the Economic Research Service ${ }^{7}$ (Appendix C). This study provided growers' share of retail value for Washington Red Delicious and Eastern Red Delicious apples marketed in New York City. The areas of production included in the eastern area were New England, New York, New Jersey, Pennsylvania, Maryland, Delaware, Virginia, West Virginia, North Carolina, and South Carolina. An analysis of apple prices in Baltimore and New York City indicated very little difference in price between the two cities. Therefore, New York data were used since it was the only eastern city for which a growers' share of retail value for Washington apples was reported. Growers' share for each month, October through June, was available for the years needed. Data from 1969-73 for each month were averaged to get a representative growers' share of retail value by month. Growers' gross returns were obtained by multiplying total retail value by the growers' average share of retail value.

Storage Cost. Storage cost of apples was taken from a 1974 study by Lee. ${ }^{8}$ His findings are not out of date with the data used in this study. For both regular storage (RS) and CA storage the cumulative seasonal costs for storing apples at monthly intervals were computed by Lee for a storage facility of 100,000 carton capacity (Appendix D).

Cost figures were derived with the assumption that all the apples would be removed from storage at the end of each month. RS was based on 150 days of storage and CA storage on 240 days. A minimum storage period of 90 days is generally required by law before apples are sold as CA storage. ${ }^{9}$

Growers' Net Return. The growers' net return was obtained by subtracting the total storage cost from growers' gross return. The net return is what the grower had left to pay for production and marketing costs, excluding storage cost.

\section{ANALYSIS OF SOLUTIONS AND ALTERNATIVES}

The season used in the study contained nine months, October to June, which involves the marketing of fall apples. Since Washington and West Virginia were the two largest suppliers of apples in the Baltimore wholesale market, their

${ }^{6}$ Growers' gross return is the amount of money the grower receives.

${ }^{7}$ Burns, loc. cit.

${ }^{8}$ Gregory Lee and Robert L. Jack, Economic Analysis of Controlled Atmosphere Apple Storage, West Virginia University Agricultural Experiment Station, Bulletin 634 (Morgantown, West Virginia: College of Agriculture and Forestry, November 1974).

${ }^{9}$ Ibid. pp. 5-11. 
TABLE 1

Annual Unloads of Apples in Baltimore Wholesale Market Broken into Fall and Spring Markets, 1967-73 ${ }^{\mathrm{a}}$

\begin{tabular}{|c|c|c|c|c|c|c|}
\hline \multirow[b]{2}{*}{ Year } & \multicolumn{2}{|c|}{ Washington } & \multicolumn{2}{|c|}{ West Virginia } & \multicolumn{2}{|c|}{ Others } \\
\hline & Pounds & $\begin{array}{l}\text { Percent } \\
\text { of Total }\end{array}$ & Pounds & $\begin{array}{l}\text { Percent } \\
\text { of Total }\end{array}$ & Pounds & $\begin{array}{l}\text { Percent } \\
\text { of Total }\end{array}$ \\
\hline & \multicolumn{6}{|c|}{ Fall } \\
\hline 1967 & $2,265,250$ & 36 & $6,098,750$ & 82 & $9,200,400$ & 70 \\
\hline 1968 & $1,672,800$ & 31 & $7,004,850$ & 83 & $8,782,200$ & 63 \\
\hline 1969 & $2,230,400$ & 34 & $8,259,450$ & 87 & $9,026,150$ & 64 \\
\hline 1970 & $1,966,050$ & 31 & $4,527,950$ & 72 & $8,783,900$ & 68 \\
\hline 1971 & $1,453,500$ & 29 & $5,316,750$ & 73 & $8,109,000$ & 68 \\
\hline 1972 & $2,830,500$ & 50 & $3,748,500$ & 72 & $6,923,250$ & 70 \\
\hline \multirow[t]{2}{*}{1973} & $3,251,000$ & 53 & $2,371,500$ & 78 & $5,699,250$ & 69 \\
\hline & \multicolumn{6}{|c|}{ Spring } \\
\hline 1967 & $3,972,900$ & 64 & $1,414,300$ & 18 & $4,321,400$ & 30 \\
\hline 1968 & $3,659,250$ & 69 & $1,394,000$ & 17 & $5,053,250$ & 37 \\
\hline 1969 & $4,251,700$ & 66 & $1,219,750$ & 13 & $5,122,950$ & 36 \\
\hline 1970 & $4,437,000$ & 69 & $1,759,500$ & 28 & $4,092,750$ & 32 \\
\hline 1971 & $3,519,000$ & 71 & $1,950,750$ & 27 & $3,825,000$ & 32 \\
\hline 1972 & $2,830,500$ & 50 & $1,453,500$ & 28 & $3,021,750$ & 30 \\
\hline 1973 & $2,869,000$ & 47 & 688,500 & 22 & $2,601,000$ & 31 \\
\hline
\end{tabular}

${ }^{a}$ United States Department of Agriculture, Fresh Fruit and Vegetable Unloads in Eastern Cities, 1967-73 (Washington, D.C.: Consumer and Marketing Service, Fruit and Vegetable Division, Market News Branch)

quantities were listed separately; all other states were included in the "other" category.

Over the past 20 years West Virginia growers have faced increased competition from other states selling fresh apples in eastern markets. During this time, the seasonal market pattern for Appalachian growers has changed very little. West Virginia, Virginia, and North Carolina continue to unload large quantities of apples early in the season, while Washington, New York, and Michigan increase their marketings late in the season. ${ }^{\mathbf{1 0}}$ As shown in Table 1, West Virginia producers did make some changes in their marketing pattern around

${ }^{10}$ Desmond O'Rourke, Recent Trends in Costs, Marketing Margins and Prices of Washington Apples, Washington Agricultural Experiment Station, College of Agriculture, Washington State University, Circular 560, January 1973, p. 16. 
1970. Washington continued marketing a lower percentage in the fall market and a higher percentage in the spring market until 1972 and 1973. Other states have continued to use the same marketing pattern for all of the years. Washington and West Virginia account for nearly 50 percent of the unloads in the Baltimore market, while other states make up the remainder.

\section{Normal Marketing Pattern - Solution I}

In the normal marketing pattern solution (Solution I), storage cost and five-year average monthly data for volume, retail price, marketing margin, and growers' return were determined for apples sold by all states in the Baltimore fresh market. West Virginia growers marketed 5,052,000 pounds for an average season. The monthly quantity for the average season ranged from a low of 38,000 pounds in June to a high of $1,098,000$ pounds in October (Table 2). The usual marketing pattern during a season showed a large quantity of sales soon after harvest, diminishing through the winter and spring months. This pattern of marketing was found to be consistent over time for West Virginia and other Appalachian District states.

The five-year average retail price per thousand pounds in Baltimore ranged from a low of \$207 in November to a high of \$276 in June, with an average seasonal retail price of $\$ 231$. At these prices, total retail value for the $5,052,000$ pounds of West Virginia apples sold in the Baltimore market was $\$ 1,123,275$. West Virginia growers' gross return was $\$ 597,308$. After subtracting $\$ 41,907$ for storage cost, the growers' net return was $\$ 555,401$, or $\$ 110$ per thousand pounds. On a monthly basis, the growers' net return in October was $\$ 122,419$. It declined to $\$ 5,525$ in June.

\section{Reversed Marketing Pattern - Solution II}

The seasonal marketing pattern used for West Virginia in Solution I was reversed for the analysis in Solution II. Reversed market pattern means marketing June's quantity in October, while October's quantity was marketed in June. The same annual quantity of 5,052,000 pounds was maintained, but increased CA storage capacity was needed in order for this market pattern to be feasible. For this solution, the monthly quantity ranged from a low of 38,000 pounds in October to a high of $1,098,000$ pounds in June (Table 3). The marketing pattern followed during this season was one with low sales soon after harvest and high volume sales in the spring. Price flexibility coefficients were used to adjust retail price due to changes in quantity. The five-year average seasonal retail price was $\$ 232$ per thousand pounds. Retail prices ranged from a low of $\$ 217$ in November to a high of $\$ 272$ per thousand pounds in June. Total retail value of the apple sales for the season was $\$ 1,200,346$.

West Virginia growers' gross return amounted to $\$ 653,109$. After subtracting $\$ 46,549$ for storage cost, the growers' net return was $\$ 606,561$ or 


\section{TABLE 2}

Five-Year Average Analysis of Fresh Apples Sold in Baltimore Wholesale Market, with Monthly Volume, Retail Value, Storage Cost, and Growers' Return to West Virginia Based on Normal Marketing Pattern (Solution I of the Model), 1969-73a

\begin{tabular}{|c|c|c|c|c|c|c|c|c|}
\hline Month & $\begin{array}{c}\text { WV } \\
\text { Avg. Mo. } \\
\text { Vol. }\end{array}$ & $\begin{array}{c}\text { Retail } \\
\text { Price } \\
\text { Per } 1,000 \\
\text { Pounds } \\
\end{array}$ & $\begin{array}{l}\text { Total } \\
\text { Retail } \\
\text { Value } \\
\end{array}$ & $\begin{array}{l}\text { Growers' } \\
\text { Share } \\
\text { Retail } \\
\text { Value } \\
\end{array}$ & $\begin{array}{c}\text { Growers' } \\
\text { Gross } \\
\text { Return } \\
\end{array}$ & $\begin{array}{c}\text { Cumulative } \\
\text { Storage } \\
\text { Cost Per } \\
1,000 \text { Pounds } \\
\end{array}$ & $\begin{array}{c}\text { Total } \\
\text { Storage } \\
\text { Cost } \\
\end{array}$ & $\begin{array}{c}\text { Growers' } \\
\text { Net } \\
\text { Return } \\
\end{array}$ \\
\hline & 1,000 lbs. & \multicolumn{2}{|c|}{ Dollars } & Percent & \multicolumn{4}{|c|}{ Dollars } \\
\hline Oct. & 1,098 & $\$ 225$ & $\$ 247,057$ & 53.0 & $\$ 130,940$ & $\$ 7.76$ & $\$ 8,521$ & $\$ 122,419$ \\
\hline Nov. & 799 & 207 & 165,463 & 53.2 & 88,027 & 7.76 & 6,203 & 81,824 \\
\hline Dec. & 807 & 223 & 179,959 & 52.8 & 95,018 & 8.00 & 6,456 & 88,562 \\
\hline Jan. & 626 & 219 & 137,193 & 54.0 & 74,084 & 8.00 & 5,012 & 69,072 \\
\hline Feb. & 591 & 218 & 128,932 & 51.6 & 66,529 & 8.24 & 4,873 & 61,655 \\
\hline Mar. & 510 & 227 & 115,770 & 51.4 & 59,506 & 9.41 & 4,799 & 54,707 \\
\hline Apr. & 391 & 231 & 90,321 & 55.8 & 50,399 & 9.65 & 3,773 & 46,626 \\
\hline May & 191 & 252 & 48,024 & 56.0 & 26,893 & 9.88 & 1,883 & 25,010 \\
\hline June & 38 & 276 & 10,557 & 56.0 & 5,912 & 10.12 & 387 & 5,525 \\
\hline Total & 5,052 & & $\$ 1,123,275$ & & $\$ 597,308$ & & $\$ 41,907$ & $\$ 555,401$ \\
\hline Average & & $\$ 231$ & & 53.7 & & $\$ 8.76$ & & \\
\hline
\end{tabular}

${ }^{\mathrm{a}}$ Calculations in Appendix E. 
TABLE 3

Five-Year Average Analysis of Fresh Apples Sold in Baltimore Wholesale Market, with Monthly Volume, Retail Value, Storage Cost and Growers' Return to West Virginia Based on Reversed Marketing Pattern (Solution II of the Model), 1969-73a

\begin{tabular}{|c|c|c|c|c|c|c|c|c|}
\hline Month & $\begin{array}{c}\text { WV } \\
\text { Avg. Mo. } \\
\text { Vol. }\end{array}$ & $\begin{array}{l}\text { Retail } \\
\text { Price } \\
\text { Per } 1,000 \\
\text { Pounds }\end{array}$ & $\begin{array}{l}\text { Total } \\
\text { Retail } \\
\text { Value }\end{array}$ & $\begin{array}{c}\text { Growers' } \\
\text { Share } \\
\text { Retail } \\
\text { Value }\end{array}$ & $\begin{array}{c}\text { Growers' } \\
\text { Gross } \\
\text { Return }\end{array}$ & $\begin{array}{l}\text { Cumulative } \\
\text { Storage } \\
\text { Cost Per } \\
1,000 \text { Pounds }\end{array}$ & $\begin{array}{c}\text { Total } \\
\text { Storage } \\
\text { Cost }\end{array}$ & $\begin{array}{c}\text { Growers' } \\
\text { Net } \\
\text { Return }\end{array}$ \\
\hline & $1,000 \mathrm{lbs}$ & \multicolumn{2}{|c|}{ Dollars } & Percent & & \multicolumn{2}{|c|}{ Dollars } & \\
\hline Oct. & 38 & $\$ 238$ & 9,108 & 53.0 & $\$ \quad 4,827$ & $\$ 7.76$ & 297 & $\$ 4,530$ \\
\hline Nov. & 191 & 217 & 41,348 & 53.2 & 21,997 & 7.76 & 1,479 & 20,518 \\
\hline Dec. & 391 & 228 & 89,164 & 52.8 & 47,078 & 8.00 & 3,128 & 43,950 \\
\hline Jan. & 510 & 221 & 112,526 & 54.0 & 60,764 & 8.00 & 4,080 & 56,684 \\
\hline Feb. & 591 & 218 & 128,932 & 51.6 & 66,529 & 8.24 & 4,873 & 61,655 \\
\hline Mar. & 626 & 226 & 141,540 & 51.4 & 72,751 & 9.41 & 5,895 & 66,857 \\
\hline Apr. & 807 & 227 & 183,041 & 55.8 & 102,137 & 9.65 & 7,787 & 94,350 \\
\hline May & 799 & 245 & 195,902 & 56.0 & 109,705 & 9.88 & 7,897 & 101,808 \\
\hline June & 1,098 & 272 & 298,785 & 56.0 & 167,320 & 10.12 & 11,112 & 156,208 \\
\hline Total & 5,052 & & $\$ 1,200,346$ & & $\$ 653,109$ & & $\$ 46,549$ & $\$ 606,561$ \\
\hline Average & & $\$ 232$ & & 53.7 & & $\$ 8.76$ & & \\
\hline
\end{tabular}

${ }^{\mathrm{a}}$ Calculated in Appendix F. 
$\$ 120$ per thousand pounds. In October it was $\$ 4,530$, increasing to $\$ 156,208$ by June.

\section{Even Marketing Patterns - Solution III}

In this solution, West Virginia's annual quantity of 5,052,000 pounds was divided by nine to obtain an even monthly quantity of 561,000 pounds sold in the Baltimore market. Changing West Virginia's marketing pattern to an even monthly distribution eliminated the problem of a large number of unloads early in the season, as in past seasons, or late in the season as in Solution II.

Retail price was adjusted by price flexibility coefficients to account for changes in quantity. The five-year average retail price per thousand pounds ranged from a low of $\$ 211$ in November to a high of $\$ 274$ in June, with an average seasonal retail price of $\$ 232$. Total retail value was $\$ 1,107,180$ (Table 4).

West Virginia growers' gross return was $\$ 630,028$. Subtracting storage costs of $\$ 44,245$ left growers a net return of $\$ 585,783$, or $\$ 116$ per thousand pounds. On a monthly basis, the growers' net return was $\$ 58,626$ in November, increasing to $\$ 80,476$ in June.

This even marketing pattern (Solution III) solution served as the basis for determining the impact the three following alternatives would have on West Virginia growers' net return.

\section{Washington Quantity Decreased - Alternative I}

After apple sales from West Virginia were placed on an even monthly marketing pattern (Solution III) in the Baltimore market, the impact of a change in Washington apple unloads on the market price was analyzed in Alternative I. The quantity from Washington was decreased each month by ten percent below the five-year average for that month. West Virginia still followed the same even market pattern of 561,000 pounds per month. The monthly quantity other states unloaded in the Baltimore market remained unchanged from the five-year average used in the basic model.

The first effect was an increase in retail prices each month. Price flexibility coefficients were used to adjust retail price due to change in quantity. The five-year average retail prices ranged from a low of $\$ 212$ per thousand pounds in November to a high of $\$ 274$ per thousand pounds in June, with an average seasonal retail price of $\$ 232$. The increased retail prices resulted in a total value of $\$ 1,173,307$ for West Virginia apples sold (Table 5).

Total annual growers' gross return was $\$ 631,731$. After subtracting storage costs of $\$ 44,245$, growers' net return for the season was $\$ 587,487$, or $\$ 116$ per thousand pounds. The lowest return was $\$ 58,856$ in November; the highest was $\$ 80,527$ in June. 
TABLE 4

Five-Year Average Analysis of Fresh Apples Sold in Baltimore Wholesale Market, with Monthly Volume, Retail Value, Storage Cost and Growers' Return to West Virginia Based on Even Marketing Pattern (Solution III of the Model), 1969-73

\begin{tabular}{|c|c|c|c|c|c|c|c|c|}
\hline Month & $\begin{array}{c}\text { WV } \\
\text { Avg. Mo. } \\
\text { Vol. } \\
\end{array}$ & $\begin{array}{c}\text { Retail } \\
\text { Price } \\
\text { Per } 1,000 \\
\text { Pounds } \\
\end{array}$ & $\begin{array}{l}\text { Total } \\
\text { Retail } \\
\text { Value } \\
\end{array}$ & $\begin{array}{l}\text { Growers' } \\
\text { Share } \\
\text { Retail } \\
\text { Value } \\
\end{array}$ & $\begin{array}{c}\text { Growers' } \\
\text { Gross } \\
\text { Return } \\
\end{array}$ & $\begin{array}{c}\text { Cumulative } \\
\text { Storage } \\
\text { Cost Per } \\
1,000 \text { Pounds } \\
\end{array}$ & $\begin{array}{c}\text { Total } \\
\text { Storage } \\
\text { Cost } \\
\end{array}$ & $\begin{array}{c}\text { Growers' } \\
\text { Net } \\
\text { Return } \\
\end{array}$ \\
\hline & 1,000 lbs. & \multicolumn{2}{|c|}{ Dollars } & Percent & \multicolumn{4}{|c|}{ Dollars } \\
\hline Oct. & 561 & $\$ 232$ & $\$ 130,034$ & 53.0 & $\$ 68,918$ & $\$ 7.76$ & $\$ 4,356$ & $\$ 64,562$ \\
\hline Nov. & 561 & 211 & 118,387 & 53.2 & 62,982 & 7.76 & 4,356 & 58,626 \\
\hline Dec. & 561 & 226 & 126,852 & 52.8 & 66,978 & 8.00 & 4,491 & 62,487 \\
\hline Jan. & 561 & 220 & 123,500 & 54.0 & 66,663 & 8.00 & 4,491 & 62,172 \\
\hline Feb. & 561 & 218 & 122,591 & 51.6 & 63,257 & 8.24 & 4,625 & 58,632 \\
\hline Mar. & 561 & 227 & 127,160 & 51.4 & 65,360 & 9.41 & 5,232 & 60,078 \\
\hline Apr. & 561 & 229 & 128,710 & 55.8 & 71,320 & 9.65 & 5,417 & 66,403 \\
\hline May & 561 & 248 & 139,094 & 56.0 & 77,893 & 9.88 & 5,546 & 72,347 \\
\hline June & 561 & 274 & 153,852 & 56.0 & 86,157 & 10.12 & 5,681 & 80,476 \\
\hline Total & 5,052 & & $\$ 1,170,180$ & & $\$ 630,028$ & & $\$ 44,245$ & $\$ 585,783$ \\
\hline Average & & $\$ 232$ & & 53.7 & & $\$ 8.76$ & & \\
\hline
\end{tabular}

${ }^{\mathrm{a}}$ Calculations in Appendix G. 
TABLE 5

Five-Year Average Analysis of Fresh Apples Sold in Baltimore Wholesale Market, with Washington Decreased Ten Percent Each Month, Monthly Volume, Retail Value, Storage Cost and Growers' Return to West Virginia Based on Even Marketing Pattern

(Alternative I), 1969-73 ${ }^{\mathrm{a}}$

\begin{tabular}{|c|c|c|c|c|c|c|c|c|}
\hline Month & $\begin{array}{c}\text { WV } \\
\text { Avg. Mo. } \\
\text { Vol. }\end{array}$ & $\begin{array}{c}\text { Retail } \\
\text { Price } \\
\text { Per } 1,000 \\
\text { Pounds } \\
\end{array}$ & $\begin{array}{c}\text { Total } \\
\text { Retail } \\
\text { Value } \\
\end{array}$ & $\begin{array}{c}\text { Growers' } \\
\text { Share } \\
\text { Retail } \\
\text { Value } \\
\end{array}$ & $\begin{array}{c}\text { Growers' } \\
\text { Gross } \\
\text { Return } \\
\end{array}$ & $\begin{array}{c}\text { Cumulative } \\
\text { Storage } \\
\text { Cost Per } \\
\text { 1,000 Pounds } \\
\end{array}$ & $\begin{array}{c}\text { Total } \\
\text { Storage } \\
\text { Cost } \\
\end{array}$ & $\begin{array}{c}\text { Growers' } \\
\text { Net } \\
\text { Return }\end{array}$ \\
\hline & $1,000 \mathrm{lbs}$ & \multicolumn{2}{|c|}{ Dollars } & Percent & \multicolumn{4}{|c|}{ Dollars } \\
\hline Oct. & 561 & $\$ 232$ & $\$ 130,259$ & 53.0 & $\$ 69,037$ & $\$ 7.76$ & $\$ 4,356$ & $\$ 64,681$ \\
\hline Nov. & 561 & 212 & 118,819 & 53.2 & 63,212 & 7.76 & 4,356 & 58,856 \\
\hline Dec. & 561 & 227 & 127,144 & 52.8 & 67,132 & 8.00 & 4,491 & 62,641 \\
\hline Jan. & 561 & 220 & 123,848 & 54.0 & 66,878 & 8.00 & 4,491 & 62,387 \\
\hline Feb. & 561 & 220 & 123,107 & 51.6 & 63,523 & 8.24 & 4,625 & 58,898 \\
\hline Mar. & 561 & 227 & 127,508 & 51.4 & 65,539 & 9.41 & 5,282 & 60,257 \\
\hline Apr. & 561 & 230 & 129,125 & 55.8 & 72,052 & 9.65 & 5,417 & 66,635 \\
\hline May & 561 & 249 & 139,555 & 56.0 & 78,151 & 9.88 & 5,546 & 72,605 \\
\hline June & 561 & 274 & 153,942 & 56.0 & 86,207 & 10.12 & 5,681 & 80,527 \\
\hline Total & 5,052 & & $\$ 1,173,307$ & & $\$ 631,731$ & & $\$ 44,245$ & $\$ 587,487$ \\
\hline Average & & $\$ 232$ & & 53.7 & & $\$ 8.76$ & & \\
\hline
\end{tabular}

${ }^{\mathrm{a}}$ Calculated in Appendix H. 


\section{Washington Quantity Increased - Alternative II}

In this alternative, Washington growers' quantity for each month was increased ten percent over the five-year average for that month. Again, West Virginia maintained an even monthly quantity of 561,000 pounds (Table 6). All other states continued the five-year average past market pattern used in the basic model.

The effect on the retail prices was a decline in price each month. This effect, due to quantity change, was adjusted by a price flexibility coefficient each month. The low month was November with a price of $\$ 210$ per thousand pounds, and the high month was June with $\$ 274$ per thousand pounds. Seasonal average retail price was $\$ 231$ per thousand pounds. At these prices, total retail value for West Virginia apples sold in the Baltimore market was $\$ 1,166,953$.

West Virginia growers' gross return was $\$ 628,324$. After subtracting $\$ 44,245$ for storage cost from growers' gross return, a total of $\$ 584,080$, or $\$ 116$ per thousand pounds, was left for growers' net return. Monthly net return increased from a low of $\$ 58,365$ in February to a high of $\$ 80,426$ in June.

\section{West Virginia Quantity Increased - Alternative III}

Washington growers' impact on market price has been analyzed in Alternatives I and II. West Virginia growers' impact on the market price was analyzed in this alternative. Each month West Virginia's quantity was increased ten percent over the five-year average even-monthly pattern used in Solution III. This increased West Virginia's annual total quantity to 5,557,000 (Table 7). Although West Virginia maintained an even monthly market pattern with 617,000 pounds per month, Washington and other states continued the five-year average past marketing pattern and volume use in the basic model.

The five-year average retail price increased from a low of $\$ 210$ per thousand pounds in November to a high of $\$ 274$ per thousand pounds in June, with an average seasonal retail price of $\$ 231$. Total retail value at these prices was $\$ 1,283,510$ for West Virginia apples sold in the Baltimore fresh market. Although the retail prices declined overall, the increase in quantity marketed each month offset the effect of the price decline. Price flexibility coefficients were used to adjust retail price due to changes in quantity.

West Virginia growers' gross return was $\$ 691,090$ and storage cost increased to $\$ 48,669$ with the increase in quantity. After subtracting storage cost from growers' gross return, a total of $\$ 642,421$, or $\$ 116$ per thousand pounds was obtained for growers' net return. On a monthly basis, the growers' net return in November was $\$ 64,149$ and $\$ 88,475$ in June.

\section{Comparison of Solutions and Alternatives}

In comparing Solutions for the model, the reversed marketing pattern (Solution II) had the largest net return because a large proportion of the sales 


\section{TABLE 6}

Five-Year Average Analysis of Fresh Apples Sold in Baltimore Wholesale Market, with Washington Increased Ten Percent Each Month, Monthly Volume, Retail Value, Storage Cost and Growers' Return to West Virginia Based on Even Marketing Pattern (Alternative II), 1969-73 ${ }^{\mathrm{a}}$

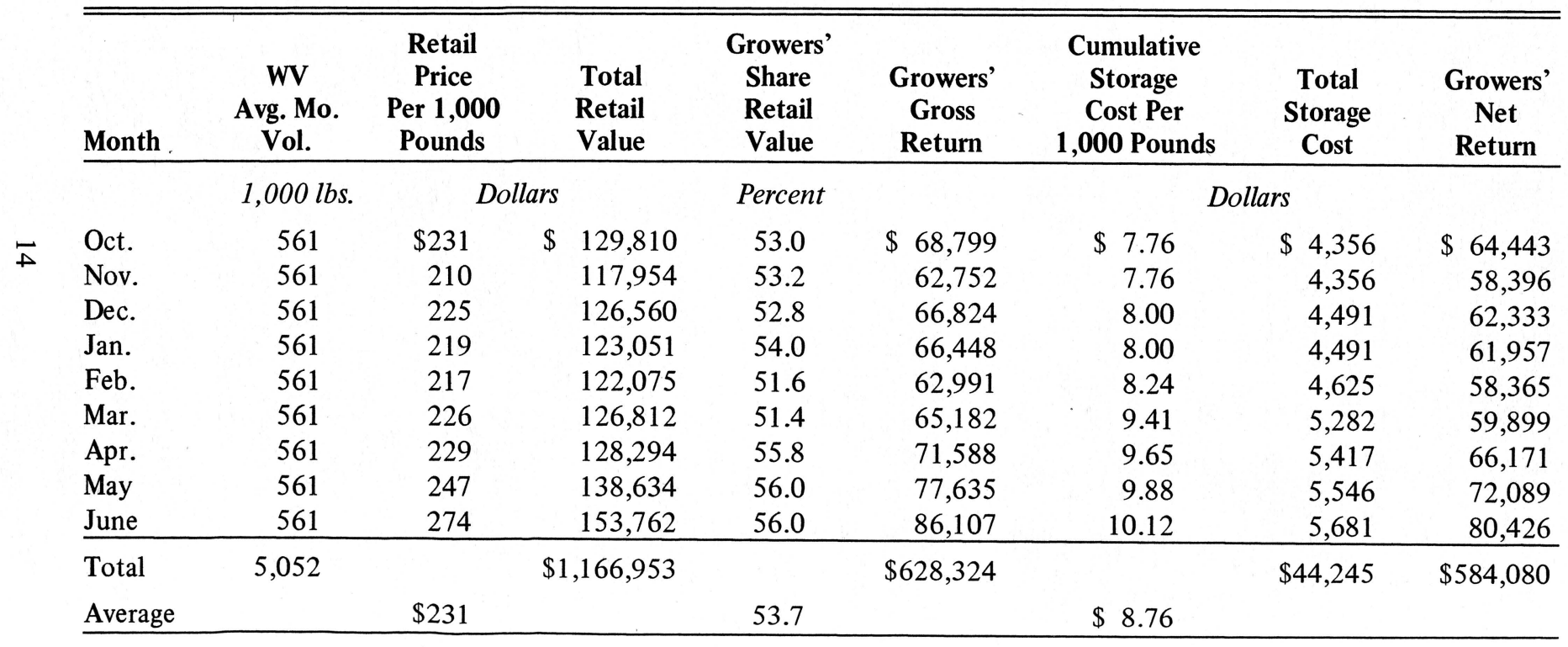

${ }^{\mathrm{a}}$ Calculations in Appendix I. 
TABLE 7

Five-Year Average Analysis of Fresh Apples Sold in Baltimore Wholesale Market, with Monthly Volume, Retail Value, Storage Cost and Growers' Return to West Virginia Based on Even Marketing Pattern Increased Ten Percent Each Month

(Alternative III), 1969-73 ${ }^{\mathrm{a}}$

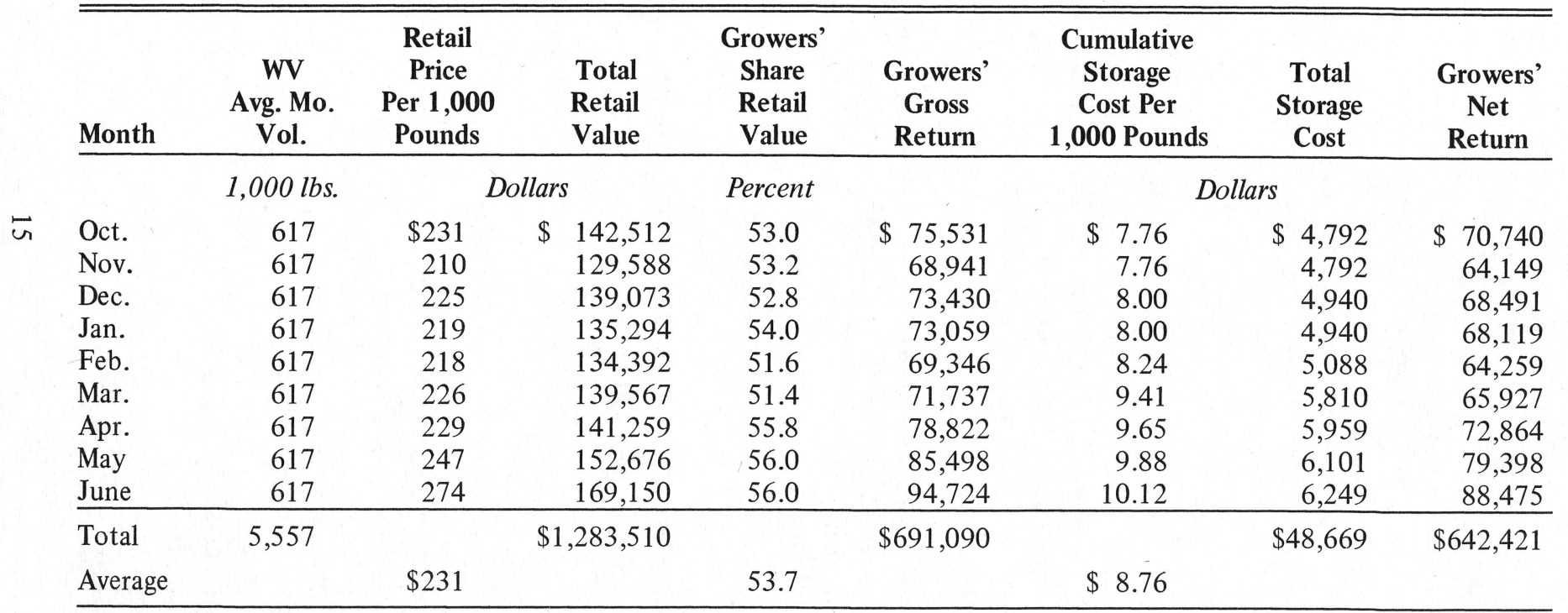

${ }^{\mathrm{a}}$ Calculations in Appendix J. 
were in the spring market season when prices are normally higher. The second largest net return occurred when the even monthly marketing pattern (Solution III) for West Virginia apples was followed (Table 8). Since the purpose of this study was to determine if the net return to West Virginia growers would be increased by changing to a more even distribution of apples over the entire market season, Solution III (even monthly distribution) was selected as the basis for comparison. The alternatives were various manipulations of quantities marketed by West Virginia and Washington to determine the effect on market price and on net return to West Virginia growers.

The impact of a smaller volume of Washington apples on the market price and on West Virginia growers' net return was considered in Alternative I. West Virginia unloads followed an even market pattern, and other states maintained the five-year average past market volume. Decreasing the volume of Washington apples increased West Virginia growers' total net return by $\$ 1,704$, but no change occurred in net return per thousand pounds. Furthermore, the increase in Washington's and West Virginia's volume in Alternatives II and III, respectively, did not change the net return per thousand pounds from that obtained in Solution III.

The analysis of Solution III and Alternative III showed adjusted net return could be increased by a more even distribution of apples over the entire market season. Another aspect which was not analyzed in this study, but which might increase adjusted net return, is a combination of Solution II and Alternative III.

TABLE 8

Comparison of Five-Year Average Net Return Between the Model Solutions and Alternatives, Baltimore Market, 1969-73

\begin{tabular}{lcc}
\hline \hline & \multicolumn{2}{c}{ Net Return } \\
\cline { 2 - 3 } The Model & Total & $\begin{array}{c}\text { Per 1,000 } \\
\text { Pounds }\end{array}$ \\
\hline Normal Marketing Pattern (Solution I) & $\$ 555,401$ & $\$ 110$ \\
Reversed Marketing Pattern (Solution II) & 606,561 & 120 \\
Even Marketing Pattern (Solution III) & 585,783 & 116 \\
Washington Quantity Decreased & 587,487 & 116 \\
(Alternative I) & & 116 \\
Washington Quantity Increased & 584,080 & 116 \\
(Alternative II) & & \\
West Virginia Quantity Increased & 642,421 & \\
(Alterative III) & & \\
\hline
\end{tabular}




\section{CONCLUSIONS}

West Virginia producers selling apples in the Baltimore fresh market are not maximizing total net return. In order to get a maximum net return, the growers should market a smaller quantity of apples in the fall market and a larger quantity in the spring market. Of the solutions and alternatives analyzed in this study, a combination of a more even distribution throughout the season (Solution III) and a ten percent increase in volume (Alternative III) unloaded in the Baltimore fresh market would be the best market pattern for West Virginia growers. Establishing this market pattern would involve more extensive use of CA storage than presently exists in West Virginia.

\section{IMPLICATIONS}

Adjustments that are made by one growing area affect growers in all other areas. With a situation where supply is increasing and demand is fairly constant, the growers must market their apple crop strategically in order to get maximum net return from sales. Also, a further suggested study dealing with market pattern shifts and impact on the growers' net return in the future years would be of interest. A study of this nature would be useful to West Virginia growers in predicting the reaction of growers in other areas to various changes in West Virginia market pattern.

West Virginia growers are not presently following the market pattern which would give the greatest net return. Under the assumptions used in this study, West Virginia could avoid the heavy sales at low prices in the fall by accepting a small increase in storage cost and switching marketing patterns. This shift in marketing pattern is essential to prevent losing sales to other growing areas and to stay competitive in the market place. This study dealt with only the Baltimore market. If the results from this analysis were applied to West Virginia fresh apples sold in all markets, the increase in net return would be much larger. 


\section{BIBLIOGRAPHY}

Burns, Alfred J. and Joseph C. Podany. Prices and Spreads For Selected Fruits Sold Fresh In Major Markets, 1967/68-1973/74. Economic Research Service, Agricultural Economic Report No. 295. Washington, D.C.: United States Department of Agriculture, August 1975.

Edman, Victor G. Retail Demand For Fresh Apples. Economic Research Marketing Research Report 952. Washington, D.C.: United States Department of Agriculture, April 1972.

Lee, Gregory and Robert L. Jack. Economic Analysis of Controlled Atmosphere Apple Storage, West Virginia University Agricultural Experiment Station, Bulletin 634. Morgantown, West Virginia: College of Agriculture and Forestry, November 1974.

O'Rourke, A. Desmond, W. Smith Greig and Albert H. Harrington. Apple Marketing Research In The Seventies. Washington Agricultural Experiment Station, Bulletin 754. College of Agriculture, Washington State University, April 1972.

United States Department of Agriculture. Farm Income State Estimates 1949-1973. Economic Research Service, FIS 224 Supplement. Washington, D.C.: September 1974.

United States Department of Agriculture. Fresh Fruit And Vegetable Unloads in Eastern Cities, 1967-1973. Consumer and Marketing Service, Fruit and Vegetable Division, Market News Branch. Washington, D.C.: December 1975.

United States Department of Labor. Estimated Retail Food Prices by Cities, 1965-1974. Bureau of Labor Statistics. Washington, D.C.: September 1975. 
APPENDIX 


\section{APPENDIX A}

Five-Year Average Estimated

Retail Apple Prices in Baltimore, 1969-73 ${ }^{\mathrm{a}}$

\begin{tabular}{lcccccc}
\hline \hline Month & $\mathbf{1 9 6 9}$ & $\mathbf{1 9 7 0}$ & $\mathbf{1 9 7 1}$ & $\mathbf{1 9 7 2}$ & $\mathbf{1 9 7 3}$ & $\begin{array}{r}\text { Monthly } \\
\text { Average }\end{array}$ \\
\hline & & & \multicolumn{4}{c}{ Cents per Pound } \\
Oct. & 26.9 & 21.3 & 18.7 & 20.6 & 25.0 & 22.5 \\
Nov. & 19.3 & 20.2 & 18.3 & 20.4 & 25.3 & 20.7 \\
Dec. & 19.9 & 18.9 & 20.3 & 26.6 & 25.9 & 22.3 \\
Jan. & 21.2 & 18.8 & 21.7 & 20.3 & 27.6 & 21.9 \\
Feb. & 21.8 & 19.5 & 17.3 & 21.3 & 29.2 & 21.8 \\
Mar. & 23.2 & 19.2 & 20.6 & 20.4 & 29.9 & 22.7 \\
Apr. & 22.5 & 21.5 & 19.5 & 22.1 & 29.8 & 23.1 \\
May & 23.7 & 22.8 & 21.3 & 24.2 & 33.9 & 25.2 \\
June & 25.2 & 26.4 & 24.7 & 25.5 & 36.3 & 27.6 \\
\hline Yearly & & & & & & \\
Average & 22.6 & 21.0 & 20.3 & 22.4 & 29.2 & \\
\hline
\end{tabular}

${ }^{\mathrm{a}}$ United States Department of Labor, Estimated Retail Food Prices by Cities, 1964-74 (Washington, D. C.: Bureau of Labor Statistics)

APPENDIX B

Price Flexibilities for Fresh Apples, by Period for Selected Seasons, 1963-64-1968-69a

\begin{tabular}{lcccc}
\hline \hline & \multicolumn{4}{c}{ Periods } \\
\cline { 2 - 5 } Season & Sep.-Nov. & Dec.-Feb. & II & III \\
Mar.-May & JV June-Aug. \\
\hline $1963-64$ & -0.4512 & -0.3634 & -0.2376 & -0.0497 \\
$1966-67$ & -.4249 & -.3432 & -.2255 & -.0475 \\
$1968-69$ & -.3727 & -.3031 & -.2012 & -.0431 \\
\hline
\end{tabular}

${ }^{\mathrm{a}}$ Victor G. Edman, Retail Demand for Fresh Apples, Economic Research Service, Marketing Research Report 952 (Washington, D.C.: United States Department of Agriculture, April 1972), pp. 12-13 


\begin{tabular}{|c|c|c|c|c|c|c|}
\hline \multirow[b]{2}{*}{ Month } & \multicolumn{5}{|c|}{ Year } & \multirow[b]{2}{*}{ Avg. } \\
\hline & 1969 & 1970 & 1971 & 1972 & 1973 & \\
\hline & \multicolumn{6}{|c|}{ Percent } \\
\hline $\begin{array}{l}\text { Oct. } \\
\text { WA } \\
\text { East }^{b}\end{array}$ & $\begin{array}{l}40 \\
48\end{array}$ & $\begin{array}{l}44 \\
47\end{array}$ & $\begin{array}{l}51 \\
\text { N.P. }\end{array}$ & $\begin{array}{l}44 \\
64\end{array}$ & $\begin{array}{l}41 \\
53\end{array}$ & $\begin{array}{l}44.0 \\
53.0\end{array}$ \\
\hline $\begin{array}{c}\text { Nov. } \\
\text { WA } \\
\text { East }\end{array}$ & $\begin{array}{l}33 \\
44\end{array}$ & $\begin{array}{l}42 \\
54\end{array}$ & $\begin{array}{l}50 \\
55\end{array}$ & $\begin{array}{l}43 \\
62\end{array}$ & $\begin{array}{l}37 \\
51\end{array}$ & $\begin{array}{l}41.0 \\
53.2\end{array}$ \\
\hline $\begin{array}{l}\text { Dec. } \\
\text { WA } \\
\text { East }\end{array}$ & $\begin{array}{l}34 \\
40\end{array}$ & $\begin{array}{l}43 \\
55\end{array}$ & $\begin{array}{l}44 \\
52\end{array}$ & $\begin{array}{l}46 \\
65\end{array}$ & $\begin{array}{l}40 \\
52\end{array}$ & $\begin{array}{l}41.4 \\
52.8\end{array}$ \\
\hline $\begin{array}{l}\text { Jan. } \\
\text { WA } \\
\text { East }\end{array}$ & $\begin{array}{l}32 \\
37\end{array}$ & $\begin{array}{l}42 \\
60\end{array}$ & $\begin{array}{l}43 \\
52\end{array}$ & $\begin{array}{l}48 \\
69\end{array}$ & $\begin{array}{l}38 \\
52\end{array}$ & $\begin{array}{l}40.6 \\
54.0\end{array}$ \\
\hline $\begin{array}{l}\text { Feb. } \\
\text { WA } \\
\text { East }\end{array}$ & $\begin{array}{l}32 \\
45\end{array}$ & $\begin{array}{l}42 \\
62\end{array}$ & $\begin{array}{l}43 \\
53\end{array}$ & $\begin{array}{l}46 \\
54\end{array}$ & $\begin{array}{l}35 \\
44\end{array}$ & $\begin{array}{l}39.6 \\
51.6\end{array}$ \\
\hline $\begin{array}{c}\text { Mar. } \\
\text { WA } \\
\text { East }\end{array}$ & $\begin{array}{l}32 \\
39\end{array}$ & $\begin{array}{l}44 \\
57\end{array}$ & $\begin{array}{l}44 \\
48\end{array}$ & $\begin{array}{l}45 \\
58\end{array}$ & $\begin{array}{l}36 \\
55\end{array}$ & $\begin{array}{l}40.2 \\
51.4\end{array}$ \\
\hline $\begin{array}{l}\text { Apr. } \\
\text { WA } \\
\text { East }\end{array}$ & $\begin{array}{l}39 \\
51\end{array}$ & $\begin{array}{l}49 \\
47\end{array}$ & $\begin{array}{l}48 \\
57\end{array}$ & $\begin{array}{l}49 \\
68\end{array}$ & $\begin{array}{l}41 \\
56\end{array}$ & $\begin{array}{l}45.2 \\
55.8\end{array}$ \\
\hline $\begin{array}{c}\text { May } \\
\text { WA } \\
\text { East }\end{array}$ & $\begin{array}{l}38 \\
49\end{array}$ & $\begin{array}{l}46 \\
63\end{array}$ & $\begin{array}{l}48 \\
62\end{array}$ & $\begin{array}{l}48 \\
65\end{array}$ & $\begin{array}{l}37 \\
42\end{array}$ & $\begin{array}{l}43.4 \\
56.0\end{array}$ \\
\hline $\begin{array}{c}\text { June } \\
\text { WA } \\
\text { East }\end{array}$ & $\begin{array}{c}39 \\
49^{c}\end{array}$ & $\begin{array}{l}44 \\
55^{c}\end{array}$ & $\begin{array}{l}45 \\
52^{c}\end{array}$ & $\begin{array}{l}46 \\
63^{c}\end{array}$ & $\begin{array}{l}46 \\
61^{c}\end{array}$ & $\begin{array}{l}44.0^{\mathrm{c}} \\
56.0^{\mathrm{c}}\end{array}$ \\
\hline $\begin{array}{l}\text { Avg. } \\
\text { WA } \\
\text { East }\end{array}$ & $\begin{array}{l}35.4 \\
44.6\end{array}$ & $\begin{array}{l}44.0 \\
55.6\end{array}$ & $\begin{array}{l}46.2 \\
47.9^{d}\end{array}$ & $\begin{array}{l}46.1 \\
63.1\end{array}$ & $\begin{array}{l}39.0 \\
51.8\end{array}$ & \\
\hline
\end{tabular}

${ }^{\mathrm{a}}$ Alfred J. Burns and Joseph C. Podany, Prices and Spreads for Selected Fruits Sold Fresh in Major Markets, 1967-68-1973-74, Economic Research Service, Agricultural Economic Report No. 295 (Washington, D.C.: United States Department of Agriculture, August 1975) pp. 3-25

${ }^{\mathrm{b}}$ East percentages include West Virginia and other states.

${ }^{c}$ Data were not available. Computed as average in comparison to other years

${ }^{d}$ Computed on eight months

$\mathrm{e}_{\text {Not published }}$ 


\section{APPENDIX D}

\section{Estimated Cumulative Storage Cost for a 100,000 Carton Regular and Controlled Atmosphere Storage Facility}

\begin{tabular}{|c|c|c|c|c|c|c|}
\hline \multirow[b]{2}{*}{ Month } & \multicolumn{2}{|c|}{$\begin{array}{l}\text { Cost Per } \\
\text { Carton }\end{array}$} & \multicolumn{2}{|c|}{$\begin{array}{l}\text { Cost Per } \\
\text { Pound }\end{array}$} & \multicolumn{2}{|c|}{$\begin{array}{c}\text { Cost Per } \\
1,000 \text { Pounds }\end{array}$} \\
\hline & $\mathbf{R S}$ & CA & $\mathbf{R S}$ & CA & $\mathbf{R S}$ & $\mathrm{CA}$ \\
\hline Oct. & $\$ .33$ & $\$ .36$ & $\$ .0077647$ & $\$ .0084705$ & $\$ 7.76$ & $\$ 8.47$ \\
\hline Nov. & .33 & .37 & .0077647 & .0087058 & 7.76 & 8.71 \\
\hline Dec. & .34 & .38 & .008 & .0089411 & 8.00 & 8.94 \\
\hline Jan. & .34 & .39 & .008 & .009176 & 8.00 & 9.18 \\
\hline Feb. & .35 & .39 & .0082352 & .009176 & 8.24 & 9.18 \\
\hline Mar. & & .40 & & .0094117 & & 9.41 \\
\hline Apr. & & .41 & & .009647 & & 9.65 \\
\hline May & & .42 & & .0098823 & & 9.88 \\
\hline June & & $.43^{b}$ & & $.010117^{b}$ & & $10.12^{b}$ \\
\hline
\end{tabular}

${ }^{\mathrm{a}}$ Lee, Gregory and Robert L. Jack, Economic Analysis of Controlled Atmosphere Apple Storage, West Virginia University Agricultural Experiment Station, Bulletin 634. Morgantown, West Virginia: College of Agriculture and Forestry, November 1974, p. 11

${ }^{b}$ Estimated by the researcher

APPENDIX E

Five-Year Average Quantities of Fresh Apples Sold in Baltimore Market From All Sources, October to June (Solution I of the Model), 1969-73

\begin{tabular}{|c|c|c|c|c|c|}
\hline \multirow[b]{2}{*}{ Month } & \multicolumn{3}{|c|}{ Source } & \multirow[b]{2}{*}{ Total } & \multirow{2}{*}{$\begin{array}{c}\text { Estimated } \\
\text { Retail Prices }\end{array}$} \\
\hline & WA & WV & Other States & & \\
\hline & & & 1,000 Pounds & & Per 1,000 Pounds \\
\hline Oct. & 267 & 1,098 & 1,644 & 3,010 & $\$ 225$ \\
\hline Nov. & 420 & 799 & 1,055 & 2,275 & 207 \\
\hline Dec. & 386 & 807 & 1,307 & 2,499 & 223 \\
\hline Jan. & 488 & 626 & 1,040 & 2,155 & 219 \\
\hline Feb. & 703 & 591 & 1,042 & 2,336 & 218 \\
\hline Mar. & 696 & 510 & 998 & 2,204 & 227 \\
\hline Apr. & 799 & 391 & 814 & 2,004 & 231 \\
\hline May & 870 & 191 & 710 & 1,770 & 252 \\
\hline June & 635 & 38 & 500 & 1,173 & 276 \\
\hline Total & 5,264 & 5,052 & 9,111 & 19,427 & \\
\hline
\end{tabular}




\section{APPENDIX F}

Five-Year Average Quantities of Fresh Apples Marketed in Baltimore Wholesale Market, with West Virginia Market Quantities Reversed ${ }^{\mathrm{a}}$, by Months, Other States' Sales as Actually Made and with Price Flexibility Included (Solution II of the Model), 1969-73

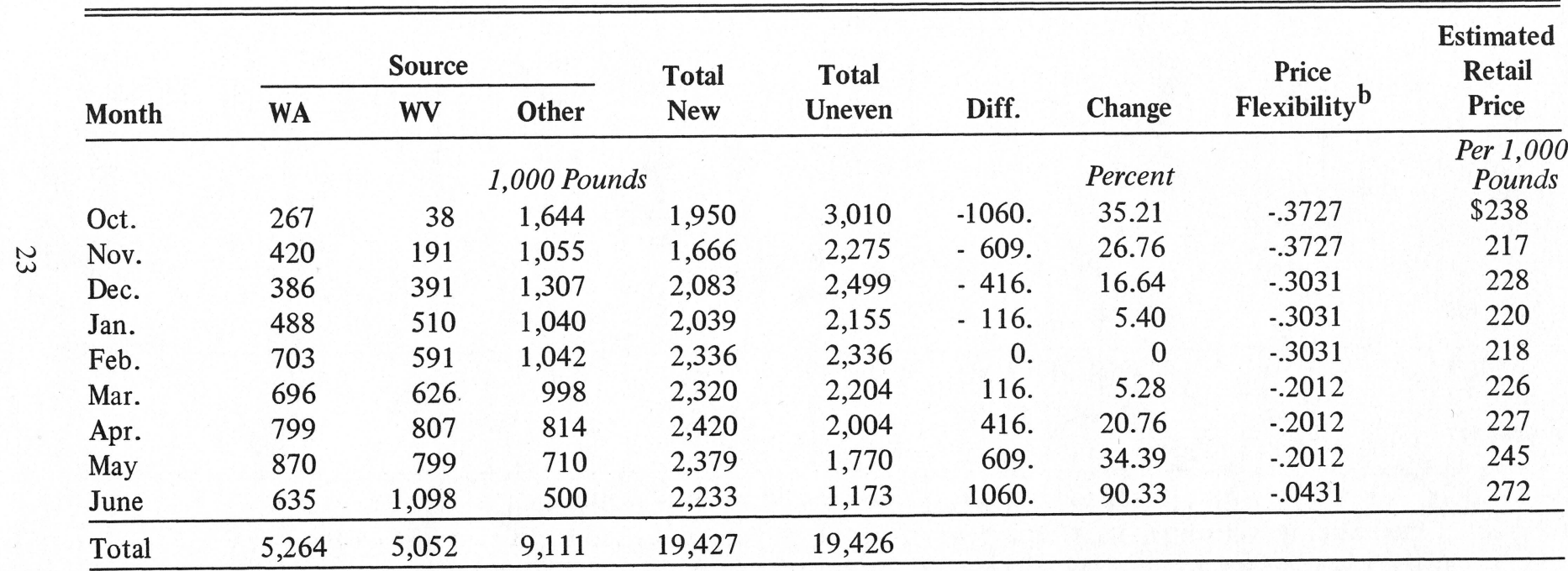

${ }^{a}$ Reversed means taking June's quantity and marketing it in October and October's quantity in June.

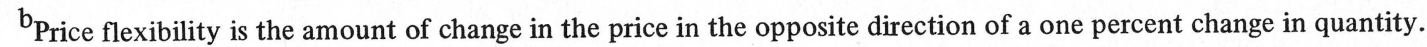




\section{APPENDIX G}

Five-Year Average Quantities of Fresh Apples Sold in the Baltimore Wholesale Market, with West Virginia Sales on Equal Monthly Distribution, all Other Sales Volumes Unchanged, and Price Flexibility Included (Solution III of the Model), 1969-73

\begin{tabular}{|c|c|c|c|c|c|c|c|c|c|}
\hline \multirow[b]{2}{*}{ Month } & \multicolumn{3}{|c|}{ Source } & \multirow{2}{*}{$\begin{array}{l}\text { Total } \\
\text { New }\end{array}$} & \multirow{2}{*}{$\begin{array}{c}\text { Total } \\
\text { Uneven }\end{array}$} & \multirow[b]{2}{*}{ Diff. } & \multirow[b]{2}{*}{ Change } & \multirow{2}{*}{$\begin{array}{c}\text { Price } \\
\text { Flexibility }\end{array}$} & \multirow{2}{*}{$\begin{array}{c}\text { Estimated } \\
\text { Retail } \\
\text { Price }\end{array}$} \\
\hline & WA & WV & Other & & & & & & \\
\hline & \multicolumn{4}{|c|}{ 1,000 Pounds } & & & Percent & & $\begin{array}{c}\text { Per } 1,000 \\
\text { Pounds }\end{array}$ \\
\hline Oct. & 267 & 561 & 1,644 & 2,473 & 3,010 & -537 & 17.83 & -.3727 & $\$ 232$ \\
\hline Nov. & 420 & 561 & 1,055 & 2,037 & 2,275 & -238 & 10.46 & -.3727 & 211 \\
\hline Dec. & 386 & 561 & 1,307 & 2,254 & 2,499 & -246 & 9.83 & -.3031 & 226 \\
\hline Jan. & 488 & 561 & 1,040 & 2,090 & 2,155 & -65 & 3.02 & -.3031 & 220 \\
\hline Feb. & 703 & 561 & 1,042 & 2,306 & 2,336 & -30 & 1.29 & -.3031 & 218 \\
\hline Mar. & 696 & 561 & 998 & 2,255 & 2,204 & 51 & 2.33 & -.2012 & 227 \\
\hline Apr. & 799 & 561 & 814 & 2,174 & 2,004 & 170 & 8.50 & -.2012 & 229 \\
\hline May & 870 & 561 & 710 & 2,141 & 1,770 & 371 & 20.94 & -.2012 & 248 \\
\hline June & 635 & 561 & 500 & 1,696 & 1,173 & 523 & 44.59 & -.0431 & 274 \\
\hline Total & 5,624 & 5,052 & 9,111 & 19,427 & 19,427 & & & & \\
\hline
\end{tabular}




\section{APPENDIX H}

Five-Year Average Quantities of Fresh Apples Sold in Baltimore Wholesale Market, with Washington

Decreased Ten Percent Each Month, West Virginia Even Distribution, Other States

Remain Same and Price Flexibility Included (Alternative I), 1969-73

\begin{tabular}{|c|c|c|c|c|c|c|c|c|c|}
\hline \multirow[b]{2}{*}{ Month } & \multicolumn{3}{|c|}{ Source } & \multirow{2}{*}{$\begin{array}{l}\text { Total } \\
\text { New }\end{array}$} & \multirow{2}{*}{$\begin{array}{l}\text { Total } \\
\text { Even }\end{array}$} & \multirow[b]{2}{*}{ Diff. } & \multirow[b]{2}{*}{ Change } & \multirow{2}{*}{$\begin{array}{c}\text { Price } \\
\text { Flexibility }\end{array}$} & \multirow{2}{*}{$\begin{array}{c}\text { Estimated } \\
\text { Retail } \\
\text { Price }\end{array}$} \\
\hline & WA & WV & Other & & & & & & \\
\hline & \multicolumn{4}{|c|}{ 1,000 Pounds } & & & Percent & & $\begin{array}{c}\text { Per } 1,000 \\
\text { Pounds }\end{array}$ \\
\hline Oct. & 241 & 561 & 1,644 & 2,446 & 2,473 & -27 & 1.08 & -.3727 & $\$ 232$ \\
\hline Nov. & 378 & 561 & 1,055 & 1,995 & 2,037 & -42 & 2.06 & -.3727 & 212 \\
\hline Dec. & 347 & 561 & 1,307 & 2,215 & 2,254 & -39 & 1.71 & -.3031 & 227 \\
\hline Jan. & 440 & 561 & 1,040 & 2,041 & 2,090 & -49 & 2.34 & -.3031 & 221 \\
\hline Feb. & 633 & 561 & 1,042 & 2,236 & 2,306 & -70 & 3.05 & -.3031 & 219 \\
\hline Mar. & 626 & 561 & 998 & 2,185 & 2,255 & -70 & 3.09 & -.2012 & 227 \\
\hline Apr. & 719 & 561 & 814 & 2,095 & 2,174 & -80 & 3.67 & -.2012 & 230 \\
\hline May & 783 & 561 & 710 & 2,054 & 2,141 & -87 & 4.06 & -.2012 & 249 \\
\hline June & 572 & 561 & 500 & 1,633 & 1,696 & -64 & 3.75 & -.0431 & 274 \\
\hline Total & 4,738 & 5,052 & 9,111 & 18,900 & 19,426 & & & & \\
\hline
\end{tabular}




\section{APPENDIX I}

Five-Year Average Quantities of Fresh Apples Sold in Baltimore Wholesale Market, with Washington Increased Ten Percent Each Month, West Virginia Even Distribution, Other States Remain Same and Price Flexibility Included (Alternative II), 1969-73

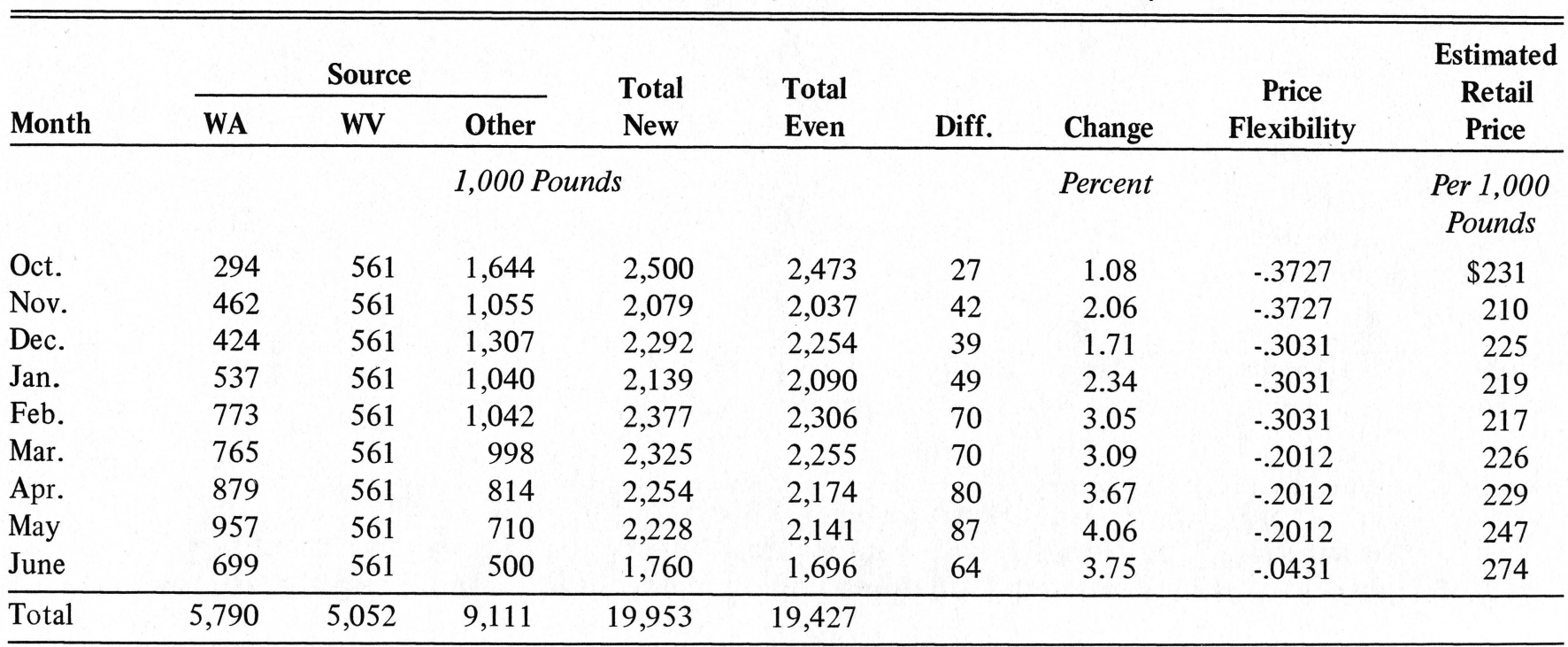




\section{APPENDIX J}

Five-Year Average Quantities of Fresh Apples Sold in Baltimore Wholesale Market, with Washington and Other States with Five-Year Average, West Virginia Increased Ten Percent Each Month with Continued Even Distribution, and Price Flexibility Included (Alternative III), 1969-73

\begin{tabular}{|c|c|c|c|c|c|c|c|c|c|}
\hline \multirow[b]{2}{*}{ Month } & \multicolumn{3}{|c|}{ Source } & \multirow{2}{*}{$\begin{array}{l}\text { Total } \\
\text { New } \\
\end{array}$} & \multirow{2}{*}{$\begin{array}{l}\text { Total } \\
\text { Even }\end{array}$} & \multirow[b]{2}{*}{ Diff. } & \multirow[b]{2}{*}{ Change } & \multirow{2}{*}{$\begin{array}{c}\text { Price } \\
\text { Flexibility } \\
\end{array}$} & \multirow{2}{*}{$\begin{array}{c}\text { Estimated } \\
\text { Retail } \\
\text { Price } \\
\end{array}$} \\
\hline & WA & WV & Other & & & & & & \\
\hline & \multicolumn{5}{|c|}{ 1,000 Pounds } & & Percent & & $\begin{array}{c}\text { Per } 1,000 \\
\text { Pounds }\end{array}$ \\
\hline Oct. & 264 & 617 & 1,644 & 2,529 & 2,473 & 56 & 2.27 & -.3727 & $\$ 231$ \\
\hline Nov. & 420 & 617 & 1,055 & 2,093 & 2,037 & 56 & 2.76 & -.3727 & 210 \\
\hline Dec. & 386 & 617 & 1,307 & 2,310 & 2,254 & 56 & 2.49 & -.3031 & 225 \\
\hline Jan. & 488 & 617 & 1,040 & 2,146 & 2,090 & 56 & 2.69 & -.3031 & 219 \\
\hline Feb. & 703 & 617 & 1,042 & 2,363 & 2,306 & 56 & 2.43 & -.3031 & 218 \\
\hline Mar. & 696 & 617 & 998 & 2,311 & 2,255 & 56 & 2.49 & -.2012 & 226 \\
\hline Apr. & 799 & 617 & 814 & 2,231 & 2,174 & 56 & 2.58 & -.2012 & 229 \\
\hline May & 870 & 617 & 710 & 2,197 & 2,141 & 56 & 2.62 & -.2012 & 247 \\
\hline June & 635 & 617 & 500 & 1,752 & 1,696 & 56 & 3.31 & .0431 & 274 \\
\hline Total & 5,264 & 5,557 & 9,111 & 19,932 & 19,427 & & & & \\
\hline
\end{tabular}


Blank Page in Original Bulletin 
Blank Page in Original Bulletin 